\title{
Effects of a new water disinfection technology on water quality
}

\author{
Artur Jachimowski ${ }^{1, *}$ \\ ${ }^{1}$ Department of Product Technology and Ecology, Faculty of Commodity Science and Product \\ Management, Krakow University of Economics, Rakowicka 27, 31-510 Kraków, Poland
}

\begin{abstract}
The article assesses the effects of use of ultraviolet radiation and electrolytically generated sodium hypochlorite on the quality of drinking water produced at "Raba" plant of the Municipal Water and Sewerage Company in Cracow as well as in the water supply network. The analysis included selected microbiological indicators, total organic carbon, water chlorination products from the group of trihalomethanes and free chlorine. The research conducted indicated that disinfectant change caused quantitative changes in THMs and free chlorine in water supplied to the water supply network. After an upgrade of the chlorination plant in 2014, an increase in water disinfection by-products at most of the tested points of the water supply network was observed. A sudden decrease in free chlorine in the distribution system was also observed in that period, whereas a bacteriological water analysis confirmed the effectiveness of use of the new water disinfection technology.
\end{abstract}

\section{Introduction}

Depending on the choice of water treatment process, there is a risk of new hazardous substances forming as by-products of water disinfection. Therefore, water companies must rise to the challenge by taking into account in their operation issues concerning water sources as well as raw water intake and treatment.

The tightening of regulations concerning the quality of water in its distribution system necessitates application of new solutions with regard to its disinfection. In order to improve the quality, safety, reliability and above all efficiency of the water disinfection process, a lot of water treatment plants search for new alternative solutions for gaseous chlorine.

As part of the systematic efforts towards improving the quality of water supplied to the inhabitants of Krakow, the decision was made to eliminate gaseous chlorine from the disinfection process at the largest plant, which is one of the last plants using this kind of disinfectant. It was decided to apply disinfection by means of sodium hypochlorite obtained from table salt and additionally UV lamps the radiation of which improves bacteriological safety of water and makes it possible to use smaller doses of the disinfectant. The main advantage of the new disinfection technology is improved quality of the water being treated

\footnotetext{
* Corresponding author: artur.jachimowski@uek.krakow.pl
} 
and its bacteriological safety as well as the elimination of the chlorine odour in drinking water.

The purpose of the article was to determine the impact of a newly implemented water disinfection technology, based on the use of UV radiation and sodium hypochlorite produced in electrolysers, on water quality at "Raba" Water Treatment Plant of the Municipal Water and Sewerage Company in Cracow as well as in the water supply network. What was employed to this end was an analysis of selected water quality parameters determined in 2011-2017, i.e. before and after the implementation of the above technology.

This paper presents the results of research on the content of chlorination by-products from the group of THMs in water after the treatment process, whereas the analysis of the total number of microorganisms at a temperature of $22^{\circ} \mathrm{C}$, free chlorine concentration, total organic carbon (TOC) and $\Sigma$ THM was carried out for water drawn from the supply area at "Raba" Water Treatment Plant.

\subsection{Effects of disinfection on water quality}

What ensures microbiological water purity in treatment technologies used nowadays is disinfection whose purpose is to remove, destroy or deactivate all forms of pathogenic organisms. It constitutes the last stage of the process of treatment and can be achieved using physical or chemical methods.

The physical methods of disinfection include UV radiation which does not change the taste, odour or physicochemical composition of water. Ultraviolet radiation is part of electromagnetic radiation with a wavelength of 100-400 nm. It has an bactericidal effect on microbes in the range of 200-280 $\mathrm{nm}$. The effectiveness of UV radiation depends on the colour and turbidity of water to be disinfected. Furthermore, it decreases as a linear function of distance from the UV lamp. The effect of disinfection with UV rays may be reduced in the event of presence of suspensions and colloidal particles in the water as they can absorb some portion of the rays. Nevertheless, the effectiveness of the disinfection process does not depend on the $\mathrm{pH}$ value or the presence of reduced organic and inorganic substances in the water. This method does not produce any by-products resulting from reactions with organic matter. Nonetheless, the absence of a disinfectant remaining in the water can promote secondary contamination in the distribution network. Therefore, this technique is most often used in combination with chlorination using sodium hypochlorite, chloramination or disinfection by means of chlorine dioxide [1-5].

Chemical disinfection consists in introduction of chemical substances into the water which destroy microbes. The effectiveness of action of a chemical agent depends on: concentration and type of bacteria living in the water, time of contact of microorganisms with the disinfecting agent and physicochemical properties of water $[1,4,6]$. Currently, the following agents are used to disinfect water: chlorine gas, chlorine(IV) oxide $\left(\mathrm{ClO}_{2}\right)$, iodine, ozone, sodium chlorate(I) solution (sodium hypochlorite solution - NaOCl), and calcium chlorate(I) solution (calcium hypochlorite solution - $\left.\mathrm{Ca}(\mathrm{OCl})_{2}\right)$ [1-4].

The water treatment process includes prechlorination (facilitating coagulation and degelling) and proper chlorination (intended to disinfect water). The intensity of chlorine reaction in the water and the requirements following from regulations determine the amount of the added disinfectant. The minimum reaction time required for proper disinfection is 20 minutes. Chlorination is a method dependent on $\mathrm{pH}$ reaction, whereas the dose is selected appropriately to water quality $[1,2]$. Water is most often chlorinated using chlorine in the form of chlorine water. On the other hand, chlorine gas is dosed directly in situations requiring the use of high disinfectant doses [4]. 
In the case of chlorination of water containing organic components, chlorine derivatives of these compounds may be produced, and the taste and odour of water may deteriorate $[1,2]$. Products of reactions of halogens $(\mathrm{Cl}, \mathrm{F}, \mathrm{Br}, \mathrm{I})$ with hydrocarbons are halogen derivatives of hydrocarbons. Out of these, trihalomethanes (THMs) are of the greatest importance. These are compounds with a generalised formula of $\mathrm{CHX}_{3}$ where $\mathrm{X}$ stands for halogens. The main specimens in the group of THMs include: trichloromethane $\mathrm{CHCl}_{3}$ (chloroform), bromodichloromethane $\mathrm{HCl}_{2} \mathrm{Br}$, dibromochloromethane $\mathrm{CHClBr}_{3}$, tribromomethane $\mathrm{CHBr}_{3}$ (bromoform). These compounds are harmful to aquatic organisms and humans. Trihalomethanes are not detectable by their odour, but their presence in water presents a physiological hazard as they show mutagenic and carcinogenic properties. As a result of use of chlorine in the disinfection process, haloacetic compounds may be produced which decompose to THMs during transport of water to the consumer $[1,7,8]$. Pursuant to the Regulation of the Minister of Health dated 20 April 2010, the allowable concentration of the total sum of THMs in water intended for drinking is $100 \mu \mathrm{m} \cdot \mathrm{dm}^{-3}$ [9]. In the case of formation of trihalomethanes, the organic compounds that react with chlorine are referred to as THM precursors. THM formation precursors include: humic substances, compounds of petrochemical origin, chlorophyll $a$, metabolites of algae and bacteria, aliphatic hydroxy acids, mono-, di- and tricarboxylic acids and aromatic carboxylic acids $[1,7,10-12]$.

The most important factors determining the formation of THMs in a water supply network are their precursors and the presence of chlorine in the water. Moreover, the process of formation of THMs during water chlorination is affected by the total organic carbon (TOC) content in water, water $\mathrm{pH}$, used chlorine dose, bromine compound content, chlorination time and temperature $[6,7,10-13]$. What also causes the concentration of $\Sigma$ THM to increase is the formation of bromine THMs due to the presence of bromine ions in the water. Despite the decreasing concentration of organic carbon dissolved in chlorinated water, the portion of brominated THMs and organobromine compounds remains unchanged. As far as the disinfection process is concerned, this is of enormous importance as effective reduction of organic compound content in the water in the presence of $\mathrm{Br}^{-}$ions will not cause a significant decrease of concentration of brominated THMs [7]. Many plants also employ pre-oxidation of raw water with high potential for THM formation [14].

Active chlorine, responsible both for the process of oxidation and disinfection, is found in chlorine water as well as in all chlorine compounds used. That is why it is an important matter to determine such a dose of chlorine so that free chlorine remains in the water after disinfection (total sum of: $\mathrm{Cl}_{2}, \mathrm{HOCl}$ and $\mathrm{OH}^{-}$) [4]. The amount of free chlorine in water intended for drinking and households cannot exceed $0.3 \mathrm{mg} \cdot \mathrm{dm}^{-3}$ [9]. However, a problem of many water treatment plants is the loss of chlorine at the end of the network $[1,15]$.

\section{Research methodology}

The subject of research was water produced at "Raba" Water Treatment Plant as drawn from the network. Microbiological tests and tests of selected water quality indicators (after the treatment process as well as at water supply network points) were carried out in 2011-2017. The results of tests were made available by the Central Laboratory of MPWiK (Municipal Water and Sewerage Company) S.A. in Cracow [16]. Water drawn from the following municipal network points underwent analysis: 7 Poronińska St, 21 Chałubińskiego St, 1 Stojałowskiego St, 57 Cechowa St, 29 Babińskiego St, 3 Spółdzielców St, 40 Bieżanowska St, 3 Brożka St, 3 Gronostajowa St, 4 Kutrzeby St, 1 Kosiarzy St, 1 Rynek Podgórski St, 7 Stoczniowców St. Samples of water from selected municipal network points were taken every quarter. Basic statistical parameters were 
calculated for the selected drinking water quality parameters: mean, minimum and maximum values, standard deviation and coefficient of variation.

\section{Chlorination plant upgrade at "Raba" Water Treatment Plant}

Before the upgrade of the chlorination plant, water would flow into two tanks with clean water (after the process of filtration) where it would be disinfected using chlorine water. The treated water would be pumped through pipelines from Raba I and Raba II tanks into drinking water tanks in Gorzków with a volume of $7.5 \mathrm{~m}^{3}$ each. At a later stage, it would flow gravitationally to Siercza where it would be additionally disinfected using sodium hypochlorite. Then the water would flow into a flow splitting chamber of Piaski Wielkie Control House from where it would be flown into the water supply network of the city of Cracow.

At the turn of September and October 2014, process changes were made at the final stage of water treatment (i.e. disinfection) whereby chlorine gas had been substituted for UV radiation and sodium hypochlorite. UV radiation is a very good disinfectant, but with a short-lasting effect. Therefore, the disinfection process consists of two stages. Introduction of a second stage of water disinfection, which involves dosing of sodium hypochlorite $(\mathrm{NaOCI})$, is to ensure full microbiological safety [17].

\section{Analysis and discussion of results}

Table 1 shows the values of selected water quality indicators in the supply area corresponding to "Raba" Water Treatment Plant. It contains the mean values obtained from tests of 13 points of the water supply network before upgrade of the disinfection system and after its upgrade when, before chlorination using electrolytically generated sodium hypochlorite, the water was additionally irradiated with ultraviolet rays.

Table 1. Water quality indicator in Raba distribution system.

\begin{tabular}{|c|c|c|c|c|c|c|c|}
\hline \multirow{2}{*}{ Indicator } & \multirow{2}{*}{ Unit } & \multirow{2}{*}{ MAC } & \multicolumn{5}{|c|}{ Before upgrade } \\
\cline { 4 - 8 } & & & Mean & Min. & Max. & SD & CV [\%] \\
\hline Microorganisms* & $\mathrm{CFU} / 100 \mathrm{ml}$ & NUC** & 15.34 & 0.00 & 370.00 & 38.04 & 247.95 \\
\hline free chlorine & $\mathrm{mg} \cdot \mathrm{dm}^{-3}$ & 0.3 & 0.06 & 0.00 & 0.50 & 0.07 & 127.68 \\
\hline $\mathrm{TOC}$ & $\mathrm{mg} \cdot \mathrm{dm}^{-3}$ & $\mathrm{NUC}$ & 1.62 & 0.60 & 4.57 & 0.47 & 29.06 \\
\hline$\Sigma \mathrm{THM}$ & $\mu \mathrm{g} \cdot \mathrm{dm}^{-3}$ & 100 & 20.63 & 0.00 & 48.60 & 9.86 & 47.81 \\
\hline \multirow{2}{*}{ Indicator } & Unit & \multirow{2}{*}{ MAC } & \multicolumn{5}{|c|}{ After upgrade } \\
\cline { 4 - 9 } & & & Mean & Min. & Max. & $\mathrm{SD}$ & $\mathrm{CV}[\%]$ \\
\hline Microorganisms & $\mathrm{CFU} / 100 \mathrm{ml}^{2}$ & NUC & 16.08 & 0.00 & 230.00 & 32.48 & 201.98 \\
\hline free chlorine & $\mathrm{mg} \cdot \mathrm{dm}^{-3}$ & 0.3 & 0.04 & 0.00 & 0.30 & 0.06 & 166.93 \\
\hline TOC & $\mathrm{mg} \cdot \mathrm{dm}^{-3}$ & NUC & 1.55 & 1.06 & 2.54 & 0.26 & 16.77 \\
\hline$\Sigma$ THM & $\mu \mathrm{g} \cdot \mathrm{dm}^{-3}$ & 100 & 23.49 & 8.50 & 72.70 & 9.43 & 40.13 \\
\hline
\end{tabular}

${ }^{*}$ total number of microorganisms at $22^{\circ} \mathrm{C}$.

** no unacceptable changes - it is recommended that the total number of microorganisms does not exceed: $100 \mathrm{CFU} / 1 \mathrm{ml}$ in water fed into the distribution network and $200 \mathrm{CFU} / 1 \mathrm{ml}$ in the tap.

Source: the author's own work based on MPWiK's results. 
The following microbiological indicators for water after the treatment process at "Raba" Water Treatment Plant and in the distribution network were analysed: Escherichia coli, enterococci (faecal streptococci), Clostridium perfringens (along with its spores) and the total number of microorganisms at $22^{\circ} \mathrm{C}$. The results for any of the determined microbiological indicators at the plant or at the analysed network points had not exceeded the allowable values specified in the standard [9], which confirmed the effectiveness of use of UV radiation and electrolytically generated sodium hypochlorite. Only in the case of the total determined number of microorganisms at $22^{\circ} \mathrm{C}$ did the mean value of this parameter increase after the upgrade (by $4.82 \% ; 16 \mathrm{CFU} / 100 \mathrm{ml}$ ) compared to the value before the disinfection method change (15 CFU/100 ml) (Fig. 1).

For free chlorine determined at 13 water supply network points in Cracow, supplied from "Raba" Water Treatment Plant, the mean concentrations before and after the water disinfection method change were calculated. Results for concentration of this indicator in a given period ranged from 0 to $0.5 \mathrm{mg} \cdot \mathrm{dm}^{-3}$ (Babińskiego $\mathrm{St}$ ), the mean value in this case being $0.06 \mathrm{mg} \cdot \mathrm{dm}^{-3}$. In contrast, in the period after the chlorination plant upgrade, the mean free chlorine content dropped by $35.93 \%$ and amounted to $0.04 \mathrm{mg} \cdot \mathrm{dm}^{-3}$ (Fig. 2).

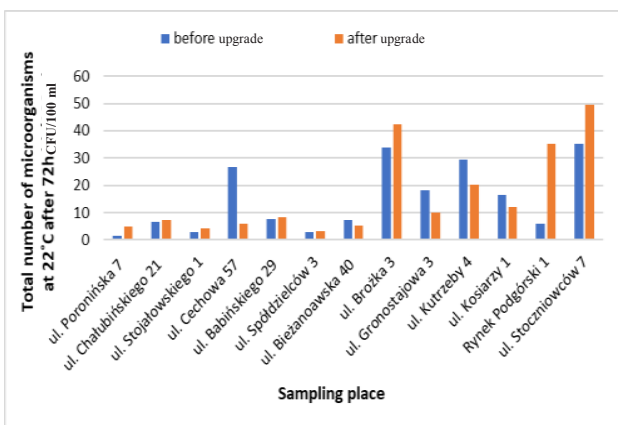

Fig. 1. Changes in the total number of microorganisms at $22^{\circ} \mathrm{C}$ after $72 \mathrm{~h}$ in water supplied from "Raba" Water Treatment Plant. Source: the author's own work based on MPWiK's results.

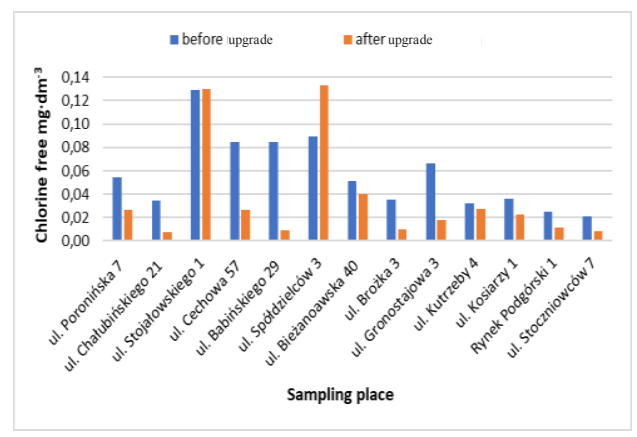

Fig. 2. Changes in free chlorine concentration in water supplied from "Raba" Water Treatment Plant. Source: the author's own work based on MPWiK's results.

The total sum of THMs in water after the disinfection process was within the range not exceeding the allowable concentrations specified in the Regulation of the Minister of Health. The highest values of this indicator were found in water disinfected with chlorine gas and varied from 0 to $31.5 \mu \mathrm{g} \cdot \mathrm{dm}^{-3}$, the mean concentration being $5.5 \mu \mathrm{g} \cdot \mathrm{dm}^{-3}$. After the disinfection system upgrade, downward trends have been observed since November 2014 whereby the concentrations of $\Sigma$ THM were running at a level of 0 to $9.7 \mu \mathrm{g} \cdot \mathrm{dm}^{-3}$, the mean in this case being $1.9 \mu \mathrm{g} \cdot \mathrm{dm}^{-3}$ (Fig. 3). The most frequently occurring compound from the group of halogen derivatives of hydrocarbons (THMs) was chloroform classified in the group of potentially carcinogenic agents for humans $[13,18]$. Chloroform, present in the water before the chlorination plant upgrade, showed the highest concentration ranging from 0 to $28.6 \mu \mathrm{g} \cdot \mathrm{dm}^{-3}$. After the new technology had been implemented, the value of this indicator varied between 0 and $9.7 \mu \mathrm{g} \cdot \mathrm{dm}^{-3}$. In contrast, the concentration of bromodichloromethane determined in the water was below the detection limit after the disinfectant change (Fig. 4). 


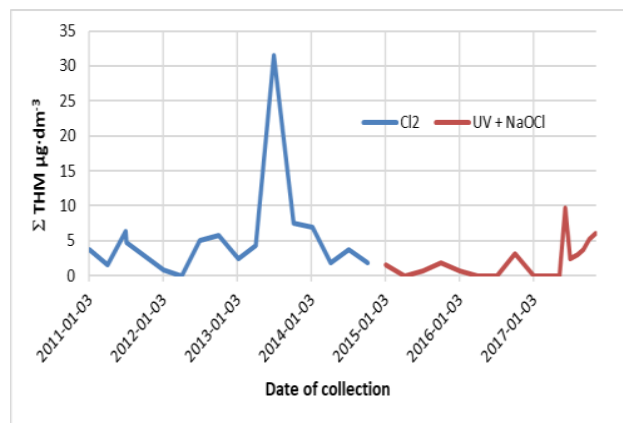

Fig. 3. Changes in concentration of $\Sigma T H M$ in water after the treatment process at "Raba" Water treatment Plant. Source: the author's own work based on MPWiK's results.

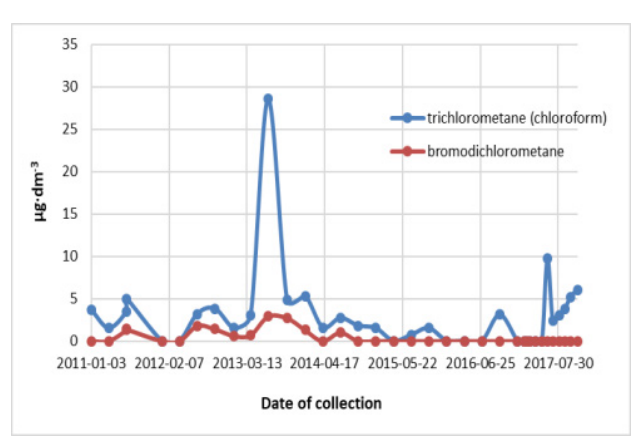

Fig. 4. Changes in concentration of compounds from the group of THMs after the treatment process at "Raba" Water treatment Plant. Source: the author's own work based on MPWiK's results.

Concentrations of $\Sigma$ THM in water from the distribution network supplied from "Raba" Water Treatment Plant, where chlorine gas had been used, were running at a level of 0 to $48.6 \mu \mathrm{g} \cdot \mathrm{dm}^{-3}$, the mean being $20.6 \mu \mathrm{g} \cdot \mathrm{dm}^{-3}$. After the chlorination plant upgrade, the concentration of this indicator ranged from 8.5 to $72.7 \mu \mathrm{g} \cdot \mathrm{dm}^{-3}$, with the mean value $\left(23.5 \mu \mathrm{g} \cdot \mathrm{dm}^{-3}\right)$ increased by $14 \%$. However, at the tested water supply network points, except for 57 Cechowa St, the concentration of the total sum of trihalomethanes increased from $3.61 \%$ to $53.92 \%$ (Fig. 5). In the period from November 2014 to November 2017, 21 Chałubińskiego St was characterised by the greatest variation $-\mathrm{CV}=71.62 \%$. The increase in concentration of $\Sigma$ THM may be affected by the use of UV rays before chemical disinfection. According to the research conducted by Włodyka-Bergier and Bergier [5] as well as other authors [19-21], water disinfection by means of UV lamps combined with later chlorination can lead to an increased potential to form disinfection by-products, including compounds from the group of trihalomethanes. It has also been shown that chemical oxidation (such as ozonation) conducted earlier on in the process can affect the formation potential of these compounds. The effects of UV rays on the chlorination byproduct formation potential confirm the fact that, after upgrade of the chlorination plant at "Bielany" Water Treatment Plant (where chlorine gas had only been substituted with sodium hypochlorite produced by electrolysers from common salt), downward trends for those products were observed [22]. After the chlorination plant upgrade, a small decrease in the concentration of total organic carbon by $3.95 \%$ was observed. The mean content was $1.62 \mathrm{mg} \cdot \mathrm{dm}^{-3}$, whereas after the disinfection method change $-1.55 \mathrm{mg} \cdot \mathrm{dm}^{-3}$ (Fig. 6). 


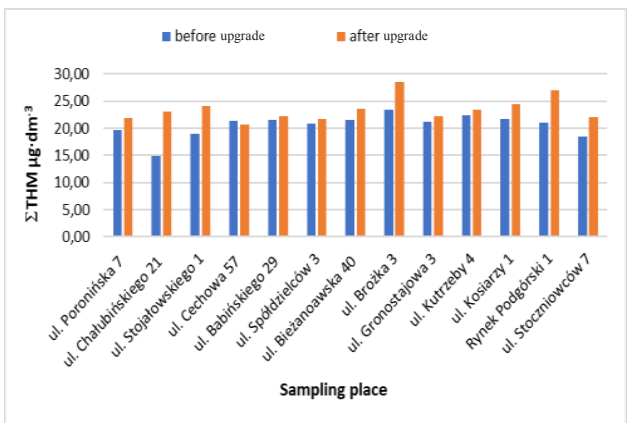

Fig. 5. Changes in concentration of $\Sigma$ THM in water supplied from "Raba" Water Treatment Plant. Source: the author's own work based on MPWiK's results.

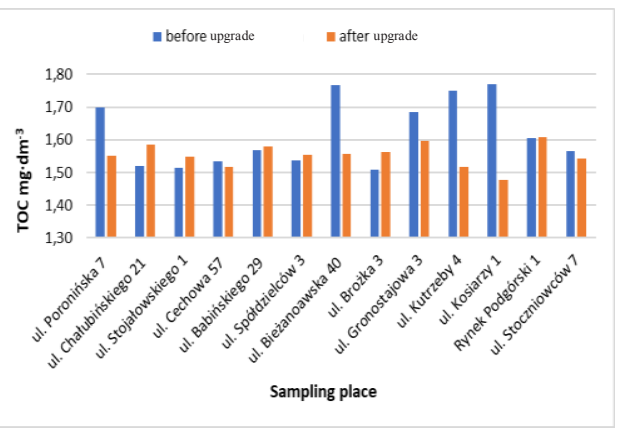

Fig. 6. Changes in concentration of TOC in water supplied from "Raba" Water Treatment Plant. Source: the author's own work based on MPWiK's results.

\section{Summary}

Ordinary common salt, which is non-toxic and easy to store in contrast to chlorine gas, is used in the system of electrolytic chlorination of water by means of sodium hypochlorite to produce a disinfecting agent. Thus, the hazard posed by chlorine gas stored at the plant is eliminated. The water disinfection system after the upgrade consisted of two stages. In the first stage, a UV disinfection system was employed due to the fact that UV rays are an excellent disinfectant, albeit with a short-lasting effect. Next, in order to obtain full microbiological safety, the application of a second stage of disinfection was envisaged, which, as already mentioned, was sodium hypochlorite produced from common salt according to the current demand. No formation of inorganic by-products (chlorates) was observed in water disinfected with electrolytically generated sodium hypochlorite. An important conclusion, which follows from the analysis of drinking water in terms of the microbiological aspects, is that the disinfecting agent used at "Raba" Water Treatment Plant is effective. In the analysis of free chlorine concentrations in water from the water supply network supplied from "Raba" Water Treatment Plant, a sudden drop of this indicator was observed at all analysed points in the period from November 2014 to November 2017. The results of tests conducted on water supplied from "Raba" Water Treatment Plant indicated that there were no effects of distance of a point from the water treatment plant on the concentrations of the determined indicators. Except for one place, an increase in $\Sigma$ THM has been observed at all tested water supply network points since November 2014. What may cause the concentration of chlorination by-products to increase is the use of UV rays which has a considerable impact on the formation potential of these compounds before chemical disinfection.

\section{References}

1. M. Gibczyńska, Hydrochemistry (University Publisher of West Pomeranian University of Technology, 2013)

2. D. Papciak, J. Zamorska, L. Kiedryńska, Microbiology and biotechnology in water treatment processes (Rzeszów: University of Technology 2011)

3. U. Raczyk-Stanisławiak, K.K. Danielak, Water disinfection [in:] J. Nawrocki (ed.) Water treatment. Physical, chemical and biological (Part 2, PWN, Warszawa, 2010) 
4. A.L. Kowal, M. Świderska-Bróż, Purification of water. Theoretical basis and technological processes and equipment (PWN, Warszawa, 2009)

5. A. Włodyka-Bergier, T. Bergier, Ochr. Środ. 35, 3, 53-57 (2013)

6. O. Hofmann, O. Hoyer, D. Schoenen, B. Wricke, Disinfection, [in:] R. Gimbel, M. Jekel, R. Ließfeld (ed.) Base and water treatment technologies (Volume 2, Bydgoszcz: PROJPRZEMKO Publishing House, 2008)

7. M. Sozański, Gaz Woda 3, 110-116 (2012)

8. J. Gumińska, M. Kłos, Technol. Wody 4, 12, 34-37 (2011)

9. Regulation of the Minister of Health on quality requirements for water intended for human consumption (Dz. U. 2017 poz. 2294)

10. I. Zimoch, The integrated method of analysis of reliability and safety of the operation of water supply systems (Silesian University of Technology, Gliwice, 2011)

11. D. Brown, J. Bridgeman, J.R. West, Reviews in Env. Sci. and Biotech. 10, 1, 79-99 (2011)

12. C. Di Cristo, G. Esposito, A. Leopardi, Environ. Technol. 34, 1, 61-70 (2013)

13. E. Zbieć, J.R. Dojlido, Ochr. Środ. 3, 74, 37-44 (1999)

14. J. Jaź-Walkowiak, M. Sozański, Zesz. Nauk. Politech. Białost., Inż. Śr. 16, 162-169 (2003)

15. A. Januszewska, I. Bojanowska, E. Ryłko, Technol. Wody 4, 12, 14-17 (2011)

16. Central Laboratory MPWiK SA, Results of laboratory analyzes of water quality indicators made at the Central Laboratory in the years 2007-2017. Own research. Cracow (2017)

17. A. Biedrzycka, NBI 5, 56, 28-31 (2014)

18. J.P. Gromiec, B. Romanowicz, W. Wesołowski, Rocz. Państ. Zakł. Hig. 47, 1, 69-76 (1996);

19. B.A. Lyon, A.D. Dotson, K.G. Linden, H.S. Weinberg, Water Res. 46, 15, 4653-4664 (2012)

20. Y. Choi, Y-J. Choi, Water Res. 44, 1, 115-122 (2010)

21. S. Weng, J. Li, E.R Blatchley, Water Res. 46, 8, 2674-2682 (2012)

22. W. Adamczyk, A. Jachimowski, Gaz Woda 2, 58-61 (2016) 